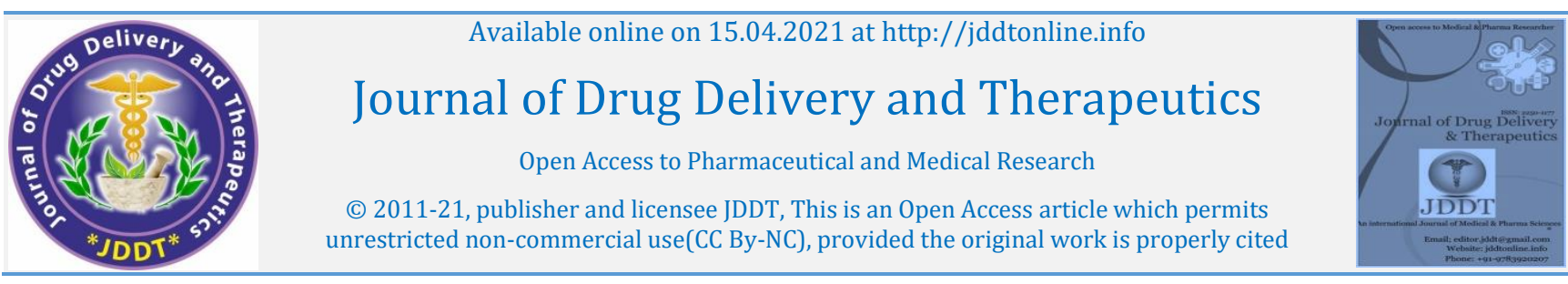

(C) 2011-21, publisher and licensee JDDT, This is an Open Access article which permits
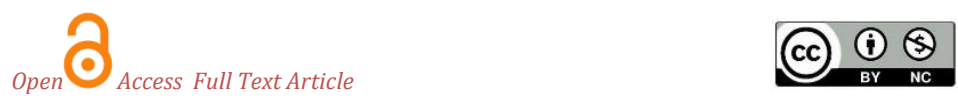

Review Paper

\title{
A review on phytochemical and pharmacological values of Aegle marmelos
}

\author{
Krushna A. Lomate*1, Krishna Murthy2, Vishal S. Adak², Rajkumar V. Shete 4 \\ 1. M. Pharm. Student, Department of Pharmacology, Rajgad Dnyanpeeth's College of Pharmacy, Bhor-412206 Dist- Pune (M.S) India \\ 2. Associate Professor Department of Pharmacognosy, Rajgad Dnyanpeeth's College of Pharmacy, Bhor-412206 Dist- Pune (M.S) India \\ 3. Professor Department of Pharmacology, Rajgad Dnyanpeeth's College of Pharmacy, Bhor-412206 Dist- Pune (M.S) India \\ 4. Principal, Department of Pharmacology, Rajgad Dnyanpeeth's College of Pharmacy, Bhor-412206 Dist- Pune (M.S) India
}

\section{Article Info:}

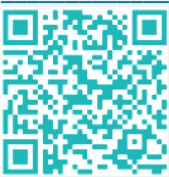

\section{Article History:}

Received 07 Feb 2021

Review Completed 24 March 2021

Accepted 30 March 2021

Available online 15 April 2021

\section{Cite this article as:}

Lomate KA, Murthy K, Adak VS, Shete RV, A review on phytochemical and pharmacological values of Aegle marmelos, Journal of Drug Delivery and Therapeutics. 2021; $11(2-s): 162-166$

DOI: http://dx.doi.org/10.22270/jddt.v11i2-s.4645

\section{*Address for Correspondence:}

Mr. Krushna A. Lomate, M. Pharm., Department of pharmacology, Rajgad Dnyanpeeth's College of Pharmacy, Bhor-412206 Dist- Pune (M.S) India

\section{Abstract}

India is the largest producer of medicinal plants and is rightly referred to as "the World's Botanical Garden." Medicinal plants play a key role in the health and vitality of humans and animals alike. Researchers have been attempting to recognize and validate plant-derived substances for the treatment of various diseases that promote compounds for health and nutrition for the past few years. Bael is a common plant that originated in India (Aegle marmelos). According to a study of the literature, entire parts of the plant, such as roots, barks, leaves, fruits, seeds, and flowers, are used to treat various diseases. Bangladesh, Indonesia, China, and other Asian countries, for example, it is a spiritual, religious, and medicinal plant that can be found all over the world. It has a number of therapeutic applications. Nowadays, various products from various parts of the plant are prepared. The biological profile, botanical description, physicochemical parameters, conventional uses, therapeutic applications and creative aspects are included in this study. The purpose of the present analysis is to compile the general chemical profile, both medicinal and economic value, value-added items such as juice, jam and toffee, and other uses of Aegle marmelos.

Keywords: Aegle marmelos, Rutaceae, Medicinal Values

\section{INTRODUCTION:}

Bael produces numerous phytochemicals that make it helpful in several illnesses, such as alkaloids, tannins, essential oils, gums, resins, coumarin, polysaccharide. The nutritional aspect, compared to other fruits, is much more essential. It is also of great significance to the environment. It serves as a climate purifier; in contrast to other plants, it releases a greater percentage of oxygen. It has various primary therapeutic applications such as antifungal, analgesic, antiinflammatory, antipyretic, hypoglycemic, anti-lipidemic, and resistant, anti-proliferative, wound, anti-fertility and insecticidal healing. With the aid of various post-harvest technologies, the fruits are also used to make a variety of items such as candy, toffee, jelly, juice, and so on. These innovations aid in the reduction of post-harvest losses, extending the shelf life of Bael products. It is therefore a good source of income for a needy farmer. ${ }^{1}$ The purpose of this analysis is to understand the phytochemical parameters, conventional uses and creative Bael fruit applications.

\section{Biological profile:}

Synonyms: The various synonyms of Bael are Hindi (Bel, bael, sripal); Sanskrit (Bilva, sriphal, shivadruma, Shivapala); Telugu (Maredu); Bengali (Bel); Gujrati (Bil); Kannada (Bilpatra, kumbala, malura); Tamil (Kuvalum); Thai (Matum and mapin); Cambodia (Phneou or pnoi); Vietnamese (Baunau);
Malayan (Majapahit); French (Oranger du Malabar); Portuguese (Marmelos); Java (Modjo). ${ }^{2}$

Ecology: Bael is an Indian ethnic group that can be found in Bangladesh, Egypt, Malaysia, Myanmar, Pakistan, Sri Lanka, and Thailand, among other places. The tree grows wild in mixed deciduous and dry forests on hills and plains in central and southern India, as well as Burma, Pakistan, and Bangladesh. ${ }^{3}$

Biophysical limits: Bael's altitude is 0-1200 m; it includes an annual mean temperature of 6 to 48 degrees Celsius and an annual mean rainfall of 570-2000 $\mathrm{mm}$. In addition, it requires well-drained soil and also grows well at pH 5 to 8 in swampy, alkaline or stony soils. 3,5

\section{Taxonomy ${ }^{4,6}$}

Kingdom: Plantae

Order: Sapindales

Family: Rutaceae

Sub family: Aurantioideae

Genus: Aegle

Species: A. marmelos

\section{Botanic Description}

Aegle marmelos is a medium-sized, slow-growing tree with a short trunk, dense, fuzzy, flaking bark, up to 12-15 m tall, and spreading with spiny branches. A clear, gummy sap, similar to arabic gum, exudes from wounded branches and hangs in 
long threads, eventually becoming solid. At first taste, it is sweet and then unpleasant to the mouth. ${ }^{4}$

Leaves: The deciduous, alternating leaves, single or 2's or 3 's, are composed of 3 to 5 oval, pointed, shallowly toothed leaflets, $4-10 \mathrm{~cm}$ long, $2-5 \mathrm{~cm}$ thick, long-petiole terminal one. When bruised, mature leaves emit a disagreeable odour. ${ }^{5}$

Flowers: Flowering occurs shortly after the new vacation in April and May. Fragrant flowers have 4 curved, fleshy petals, green outside, yellowish within, and 50 or more greenishyellow stamens in clusters of 4 to 7 along a young branch. 4

Fruits: The fruit, which is round, pyriform, oval, or oblong in shape and has a diameter of 5-20 cm, may have a thin, rough, woody shell or a gray-green rind that is more or less soft until fully ripe and becomes yellowish when fully ripe. It's lined with aromatic, minute oil glands. There's a hard central core inside, as well as 8 to 20 faintly shaped triangular segments with thin, dark-orange walls and aromatic, pale orange, pasty, sweet, resinous pulp that's more or less astringent. The fruit takes 10 to 11 months to mature from bloom to ripening. Fruits contain $61.5 \mathrm{~g}$ of water, $1.8 \mathrm{~g}$ of protein, $0.39 \mathrm{~g}$ of fat, $1.7 \mathrm{~g}$ of minerals, $31.8 \mathrm{~g}$ of carbohydrates, $55 \mathrm{mg}$ of carotene, $0.13 \mathrm{mg}$ of thiamine, 1.19 $\mathrm{mg}$ of riboflavin, $1.1 \mathrm{mg}$ of niacin and $8 \mathrm{mg}$ of vitamin $\mathrm{C}$ per $100 \mathrm{~g}$ of food. The Bael fruit, with its richest source of riboflavin, is highly nutritious. ${ }^{1}$

Seeds: 10 to 15 flattened-oblong seeds are contained in the pulp. The seeds are about $1 \mathrm{~cm}$ long, with woolly hair and each enclosed in a sack of clear, sticky mucilage that solidifies when dried. ${ }^{7}$

\section{Chemical composition:}

Aegle marmelos have a number of compound groups, such as alkaloids, cardiac glycosides, saponin, hormones, coumarins (marmelosin, marmesin, marmin, imperatorin, scopoletin), terpenoids, phenylpropenoids, tannins, flavonoids, and polysaccharides. There are $\gamma$-sitosterol, aegelin, lupeol, rutin, marmesinin, $\beta$-sitosterol, flavone, glycoside and phenylethyl cinnamides in the leaves of Aegle marmelos. Shahidine, an alkaloid with an oxazoline centre, was isolated from the fresh leaves of Aegle marmelos as a major component and demonstrated activity against a few Gram-positive bacteria. ${ }^{8}$
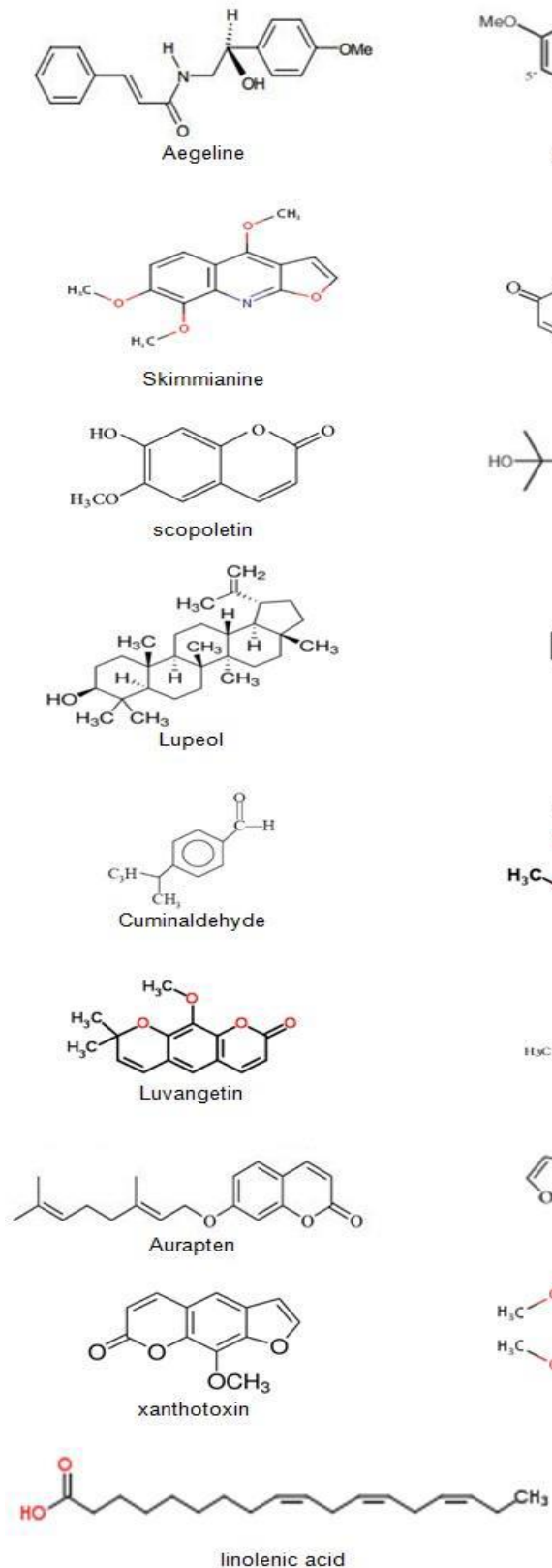
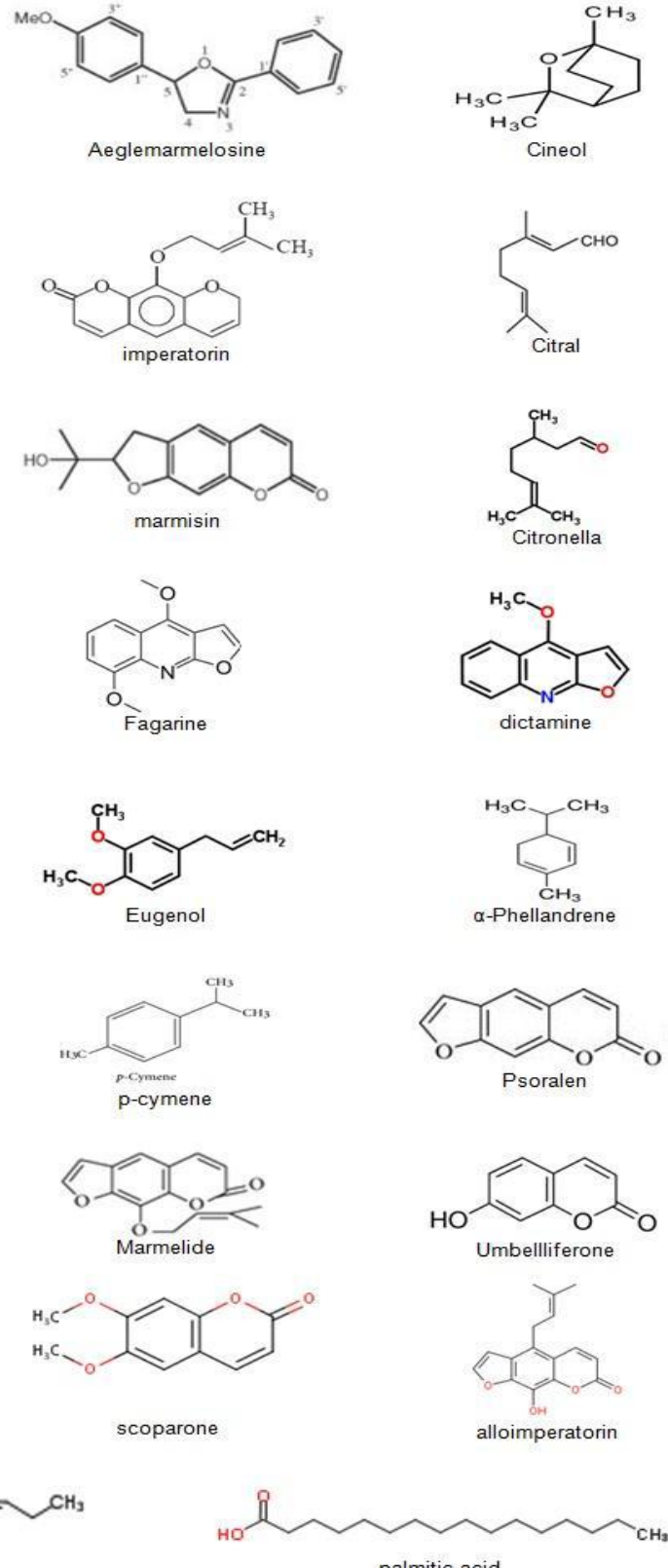

Figure 1: Phytoconstituents present in Aegle marmelos 10 
Halfordino, ethylcinnamide, and marmelin are new alkaloids discovered in the leaves of Aegle marmelos. Aegle marmelos leaves have recently yielded a number of phenylethyl cinnamides, including new compounds called anhydromarmeline, aegelinosides $\mathrm{A}$ and $\mathrm{B}$, which are glucosidase inhibitors. The common component of the essential oil from leaves, twigs and fruits was found to be alPhellandrene, which is terpenoid. Leaf oil registered alphaphellandrene (56\%) and p-cymene (17\%). The main constituent of bael leaves that are characteristic markers for the identification of Aegle marmelos oil samples was confirmed to be Limonene (82.4\%). Approx there is. In contrast to the cultivated form, $9 \%$ tannin in the pulp of wild fruits. Like skimmianine, also known as 4, 7, 8trimethoxyfuro-quinoline, tannin is also found in leaves. Hydroxycoumarins, phenylpropenes and lignans were contained in the phenylpropanoids. It's lined with aromatic, minute oil glands. There's a hard central core inside, as well as 8 to 20 faintly shaped triangular segments with thin, dark-orange walls and aromatic, pale orange, pasty, sweet, resinous pulp that's more or less astringent. The fruit takes 10 to 11 months to mature from bloom to ripening. ${ }^{9}$

\section{Therapeutic Uses and Pharmacology}

\section{Anti-cancer Activity:}

Breast cancer is among the world's most common types of cancer. It is also the leading cause of death in female cancer patients around the world. Despite multiple clinical approaches, it is nevertheless related to a high mortality rate. Aegle marmelos (L.) Correa is widely used in the Indian Ayurveda medicine system due to its unique medicinal properties. However, there are few reports on its efficacy in the fight against cancer. The aim of this study was to see if In rats induced by 7,12-dimethylbenz(a)anthracene, Aegle marmelos fruit extract could prevent breast cancer (DMBA). The rats were female Charles Foster rats, aged 55-60 days and weighing around (150 $10 \mathrm{~g})$, and they were given DMBA $(20 \mathrm{mg} / \mathrm{mL}$ dissolved in olive oil) orally. The rats were given Aegle marmelos ethanolic fruit pulp extract $(200 \mathrm{mg} / \mathrm{kg}$ b.w./day) orally for 5 weeks after developing breast tumors (about $0.5 \mathrm{~cm}$ ), and the tumor volume was assessed. The volume of mammary tumors was significantly reduced $(\mathrm{P}<0.05)$ after treatment with Aegle marmelos, as were various serum biomarkers such as TNF, serum malondialdehyde (MDA), and glucose levels $(\mathrm{P}<0.0001)$. After treatment with Aegle marmelos ethanolic fruit pulp extract, both kidney and liver serum biomarker parameters improved significantly (P0.0001). Taking all into account, the ethanolic fruit pulp extract of Aegle marmelos has antiproliferative potency in the rat model, suppressing the growth of breast tumors. Hepatoprotection is another advantage of the plant extract. As a result, it may be used to treat breast cancer as a new and successful anti-cancer drug. ${ }^{11}$ Taking all into account, it can be concluded that Aegle marmelos ethanolic fruit pulp extract has anti-proliferative efficacy by suppressing the development of breast tumors in the rat model. ${ }^{12}$

\section{Antihyperglycemic activity:}

The author gave diabetic rats Aegle marmelos leaves extract $@ 500 \mathrm{mg} / \mathrm{kg}$ to test hypoglycemic and antioxidant impact. Male albino rats were divided into three groups at random: Group I, Group II, and Group III, which included control, diabetic, and diabetic extract rats, as well as A extract rats. A. Marmelos they observed that there was a drop in blood glucose in group III animals at the end of four weeks relative to group II.13 A. Marmelos, like insulin, is effective in restoring normal blood glucose and body weight. According to new study, the leaf juice from A.Marmelos was effective in diabetes mellitus, which may be attributed to the presence of bioactive components such as aegelin, scopoletin, and sitosterol in the leaves. ${ }^{14,15}$

\section{Anti-Diarrhoea and dysentery Activity:}

Half-mature or unripe fruit serves as a cure in the case of chronic diarrhoea and dysentery without fever. Half-ripe fruit is considered best for the task, but successful results have been shown by fully ripe fruits or even fruit powder. It is sliced, dried and ground into powder while the fruit is still unripe. By baking and then eating brown sugar or jaggery, the unripe fruit can also be eaten. The amount of blood passed into the faecal matter decreases after use of fruit, and the faecal matter gets a more stable form. ${ }^{16,17}$

\section{Anticonvulsant activity:}

Extract from the aqueous leaves of $A$. marmelos has anticonvulsant efficacy against seizures caused by pentylenetetrazole in mice. The anticonvulsant function of the extract of a aqueous leaves A. marmelos was attributed to the existence of mass spectrometry detected by liquid chromatography of Lupeollinoleate, Skimmianine, Eugenol. Ethanolic leaf extract from A. marmelos reveals anticonvulsant activity due to flavonoid presence and interferes with the anticonvulsant activity of the GABAergic mechanism. ${ }^{18,19}$

\section{Antimicrobial activity:}

It is confirmed that A. marmelos are traditionally used to inhibit a wide variety of pathogenic microorganisms for the treatment of different infectious diseases. Antibacterial activity of leaves and fruit extract A was evaluated by the reviewer. A. marmelos. Inhibition zones of $11 \mathrm{~mm}$ and $9 \mathrm{~mm}$ were observed when leaf and fruit extracts were used against Roultella plantikola. The plant extract Penicillium chrysogenum provided the maximum inhibition zone (18 $\mathrm{mm}$ ) activity against fungal strains and the minimum inhibition zone $(18 \mathrm{~mm})$ activity against Candida albicans $(7 \mathrm{~mm}) .^{20}$

\section{Anxiolytic and antidepressant:}

Extract from the methanolic leaves of $A$. marmelos has anxiolytic and antidepressant activity, and imipramine and fluoxetine improve anxiolytic and antidepressant activity. ${ }^{21}$

\section{Antioxidant activity}

Antioxidants have the potential to defend cells from oxidative stress through scavenging free radicals. Flavones, isoflavones, flavonoids, anthocyanins, coumarins, lignans, catechins, and isocatechins are all antioxidants found in these plants. Antioxidant activity against a variety of free radicals is well established in A. marmelos. Another research found antioxidant activity in A. leaf extract. A. marmelos was responsible for the high levels of total phenolic content (TPC) and total flavonoid content (TFC) in the extract. ${ }^{22,23}$

\section{Anti-inflammatory activity}

The author has tested the anti-inflammatory, antipyretic and analgesic efficacy of various extracts of Aegle marmelos leaves. The extracts provided a substantial inhibition of paw edoema induced by carragenin and cotton pellet granuloma in rats. The leaves, due to the presence of lupeol, skimmianine, displayed anti-inflammatory properties. ${ }^{24,25}$

\section{Analgesic activity}

At doses of 200 and $300 \mathrm{mg} / \mathrm{kg}$, extract from the methanolic leaves of $A$. marmelos showed substantial analgesic activity 
in mice in acetic acid-induced writhing and tail flick studies. $^{26}$

\section{Antifungal activity}

According to research by Rana et al. (1997), essential oil from Aegle marmelos leaves can interfere with the metabolism pathway of $\mathrm{Ca}^{2+}$ dipicolonic acid and may inhibit the development of spores at a concentration of $500 \mathrm{ppm}$. Extract of A. ethanolic, methanolic and water leaves. $A$. marmelos has antifungal action against fungal dermatophytes. ${ }^{27}$

\section{Neuroprotective activity}

In male rats, an extract of ethanolic leaves from A. marmelos displayed neuroprotective effects against streptozocineinduced cognitive impairment. In addition, the extract inhibited acetylcholinesterase activity in the brain (AChE). AChE inhibition decreases the effects of cognitive deficits by increasing acetylcholine levels. ${ }^{28}$

\section{Anti-ulcer activity}

Methanolic extract of Aegle marmelos unripe fruit decreased gastric ulceration and prevented oxidative stress in rats caused by Helicobacter pylori-Lipopolysaccharide. The presence of luvangetin, which reduces oxidative stress in the gastroduodenal mucosa, contributed to the extract's gastroprotective impact. Some other research has indicated the ripe fruit of $A$. The antisecretory and cytoprotective property of $A$. marmelos protects gastric mucosa in NSAID induced ulceration in rats (Singh and Guha, 2012). Methanolic and aqueous extract of fruit seeds from $A$. Marmelos demonstrated antiulcer activity due to the presence of the compound quercetin. 29,30

\section{Antiviral activity}

Antiviral activity against the Ranikhet disease virus was demonstrated by the ethanolic Bael fruit extract. Bael fruit produces marmilide, the most powerful viricidal agent that interferes with the replicating period of early events. ${ }^{31}$

\section{Immunomodulatory activity}

Methanolic leaves have been found to extract A. In rats, $A$. marmelos activate cell-mediated and antibody-mediated immune responses, but the low dose of Aegle marmelos methanolic extract was found to be most effective in cellmediated immune responses, whereas the high dose was the most effective in humoral immunity. ${ }^{32,33}$

\section{Diuretic}

Sharma GN et al observed that, at a higher dose $(500 \mathrm{mg} / \mathrm{kg})$, ethanolic extract induces a substantial increase in sodium excretion. An effective solvent is also present in petroleum ether, chloroform and ethyl acetate fractions. ${ }^{30}$

\section{Antifertility}

Ethanolic leaf extracts from A. marmelos. The motility of the sperm had a major effect on $A$. marmelos. Increased concentration of extracts has also been suggested to reduce sperm motility. ${ }^{30}$

\section{Toxicological studies}

From the leaves of A, complete alcoholic, total aqueous, whole aqueous and methanolic extracts were obtained. However, no adverse effects up to a maximum dose of 250 $\mathrm{mg} / \mathrm{kg}$ body weight have been recorded with marmelos. ${ }^{34}$

\section{Constipation}

As the best of all known laxatives, ripe fruit has been considered. The administration of ripe fruits cleans and tonifies the intestines in the event of constipation. Its daily usage for 2-3 months was successful in eliminating old and accumulated faecal matter from the intestines. The pulp of ripe fruit is crushed and created into a sherbet for the best results. To decrease the bitterness, seeds are omitted and sugar and/or milk can be added to make it more palatable.

\section{Conclusion:}

The therapeutic and medicinal value of the Bael fruit is high. Bael's revolutionary commercial goods need to be exploited by preventing post-harvested fruit losses in order to process them into suitable products. These food products would benefit customers because of their nutritional value and their therapeutic significance. In order to find out the viewpoint on the globalization of the Bael tree, the present analysis elaborates different therapeutic and creative approaches. For the betterment of the health care system, there is a need to create, preserve and encourage conventional medicines.

\section{References:}

1. Ravani A, Joshi DC. Processing for value addition of underutilized fruit crops. Trends in Post-Harvest Technology 2014; 2:15-21.

2. Kaur A, Kalia M. Physicochemical Analysis of Bael (Aegle marmelos) Fruit Pulp, Seed and Pericarp J. Chem Sci Review and Letters 2017; 6(22):1213-1218.

3. http://www.kannadigaworld.com.

4. Kaur A, Kalia M. Physicochemical Analysis of Bael (Aegle marmelos) Fruit Pulp, Seed and Pericarp J. Chem Sci Review and Letters 2017; 6(22):1213-1218.

5. Wirth EH. Soil and plant analysis. Inter science Publication, New York. 1946; 35(6):192-192.

6. Sharma N, Dubey W. History and Taxonomy of Aegle marmelos: A Review Inter J. Pure Applied Bioscience 2013; 1(6):7-13.

7. QadryJ.S. Pharmacognosy, B.S. Prakashan, 12th edition. 2004, 05:78-79.

8. Asha J. and Krishan K. Tremendous Pharmacological Values of Aegle marmelos. International Journal of Pharmaceutical Sciences Review and Research. 2016; 36(2):121-127.

9. Neeraj. V. B. and Johar, V. Bael (Aegle marmelos) Extraordinary Species of India: A Review. International Journal of Current Microbiology and Applied Sciences. 2017; 6(3): 1870-1887.

10. Yogita Chaoudhary, Abhishek Saxena. Phytochemistry, Pharmacological and Traditional uses of Aegle marmelos. UK Journal of Pharmaceutical and Biosciences. 2017; 5(5):27-33.

11. Akhouri V, Kumari M, Therapeutic effect of Aegle marmelos fruit extract against DMBA induced breast cancer in rats. nature.com 2020; 6(3):12-17.

12. Ansari, P., Afroz, N., Jalil, S., Azad, S. B., Mustakim, M. G., Anwar, S. and Hannan, J. M. A. Anti-hyperglycemic activity of Aegle marmelos (L.) corr. is partly mediated by increased insulin secretion, $\alpha$-amylase inhibition, and retardation of glucose absorption. Journal of Pediatric Endocrinology and Metabolism. 2017; 30(1):37-47.

13. Upadhya, S., Shanbhag, K. K., Suneetha, G., Balachandra Naidu, M. and Upadhya, S. A study of hypoglycemic and antioxidant activity of Aegle marmelos in alloxan induced diabetic rats. Indian journal of Physiology and pharmacology. 2004; 48(4):476-480.

14. Maqbool, M., Gani, I. and Dar, M.A., Anti-Diabetic Effects of Some Medicinal Plants In Experimental Animals: A Review. Asian Journal of Pharmaceutical Research and Development. 2019; $7(1): 66-69$.

15. Nigam, V. and Nambiar, V.S., Aegle marmelos leaf juice as a complementary therapy to control type 2 diabetes-Randomised controlled trial in Gujarat, India. Advances in Integrative Medicine. 2019; 6:11-22.

16. Ullikashi KY, Kammar MR, Lokapure SR. Development of Value Added Products from Bael Fruit (Aegle marmelos). Int J Current Micro and Appli Sci. 2017; 6: pp. 2652-2659. 
17. Rakulini R, Kalaichelvi S. A review of Anti-Diarroheal activities of Aegle marmelos. J Complement. Alter. Med. Res.2019; 7(2):110.

18. Puthallath R.E., Joseph L., Kademane K., Rao S.N. Anticonvulsant activity of Nigella sativa, Aegle marmelos and Benincasa hispida in Pentylenetetrazole induced seizure in Swiss albino mice. Asian Journal of Medical Sciences, 2016. 7(3):97-102.

19. Patel A.R., Dipak, G., Manodeep, C. and Jagdish K., V. Aegle marmelos (L): A Therapeutic Boon for Human Health. International journal of research in ayurveda pharmacy. 2012; 3(2):159-163.

20. Meena, R., Pareek A. and Meena R. R. Antimicrobial activity of Aegle marmelos (Rutaceae) plant Extracts. International Journal of MediPharm Research. 2016; 2(1):1-5.

21. Kothari, S., Minda, M., and Tonpay, S. D. Anxiolytic and Antidepressant Activity of methanol extract of Aegle marmrlos leaves in mice. Indian journal of physiology and pharmacology. 2010; 54(4):318-328.

22. Sekar, D. K., Kumar, G., Karthik, L. and Rao, K. B. A review on pharmacological and phytochemical properties of Aegle marmelos (L.) Corr. Serr. (Rutaceae). Asian Journal of Plant Science and Research 2011; 1(2):8-17.

23. Kumar, S., Bodla, R. B. and Bansal, H. Antioxidant Activity of Leaf Extract of Aegle marmelos Correa ex Roxb. Pharmacognosy Journal. 2016; 8(5):52-56

24. Arul V., Miyazaki S., Dhananjayan R. Studies on the antiinflammatory, antipyretic and analgesic properties of the leaves of Aegle marmelos Corr. Journal of Ethnopharmacology. 2005; 96(1-2):159-163.

25. Sharma N. and Dubey W., Bioactive Compounds Present In Aegle marmelos and Their Role In Medicinal Properties: A Review. International journal of pharma and bio sciences. 2016; $7(3): 170-176$.
26. Shankarananth V., Balakrishnan N., Suresh D., Sureshpandian G., Edwin E. and Sheeja E. Analgesic activity of methanol extract of Aegle marmelos leaves. Fitoterapia. 2007; 78(3):258-259.

27. Balakumar S., Rajan S., Thirunalasundari T. and Jeeva S. Antifungal activity of Aegle marmelos (L.) Correa (Rutaceae) leaf extract on dermatophytes. Asian Pacific Journal of Tropical Biomedicine. 2011; 1(4):309-312.

28. Raheja S., Girdhar A., Kamboj A., Lather V. and Pandita D. Aegle marmelos leaf extract ameliorates the cognitive impairment and oxidative stress induced by intracerebro ventricular streptozotocin in male rats. Life sciences. 2019; 221:196-203.

29. Ramakrishna Y.G., Savithri K., Kist M. and Devaraj S.N. Aegle marmelos fruit extract attenuates Helicobacter pylori Lipopolysaccharide induced oxidative stress in Sprague Dawley rats. BMC complementary and alternative medicine. 2015; 15(1):375.

30. Sharma G.N., Dubey S.K., SatI N. and Sanadya J. Ulcer healing potential of Aegle marmelos fruit seed. Asian J Pharm Life Sci. 2011; 1(2):172-178.

31. Miranda D., Pereira L., Sirsat S. M., Antarkar D. S., and Vaidya A. B. In vitro action of Dadima (Punica granatum Linn.) against microorganisms involved in human gastrointestinal infectionsisolation and identification of tannins. Journal of Research in Ayurveda and Siddha. 1993; 14(3-4):154-164.

32. Choubey A., Choubey A., Mishra A., Mishra S. and Patil U.K. Evaluation of the immunomodulatory activity of the methanolic and ethanolic extract of leaves of Aegle marmelos in Rats. International Journal of Drug Development and Research. 2010; 2(4):844-9.

33. Govinda H.V., and Asdaq S.M.B. Immunomodulatory potential of methanol extract of Aegle marmelos in animals. Indian journal of pharmaceutical sciences. 2011; 73(2):235.

34. Veerappan A, Miyazaki S, Kadarkaraisamy M, Ranganathan D. Acute and subacute toxicity studies of Aegle marmelos Corr., an Ind. Medicinal Plant. Phytomedicine. 2007; 14(2-3):209-215. 